\title{
Examining CRM and ECRM Adoption by Greek Firms
}

\author{
Irene Samanta \\ Department of Business Administration, University of West Attica, Piraeus, Greece
}

\section{Email address:}

isamanta@uniwa.gr

\section{To cite this article:}

Irene Samanta. Examining CRM and ECRM Adoption by Greek Firms. International Journal of Systems Engineering. Vol. 3, No. 2, 2019, pp. 17-24. doi: 10.11648/j.jise.20190302.11

Received: March 14, 2019; Accepted: September 17, 2019; Published: December 16, 2019

\begin{abstract}
The aim of this research is to investigate Customer Relation Marketing characteristics in Business to Business Relations that are developed between suppliers and clients taking into account parameters of Information Technology that have been created to enhance CRM in recent years. The continuous development of Information technologies and its interaction with marketing are a resource to create value for the customer. The research was conducted in 73 Greek companies using cross-tab analysis to investigate the possible relation of IT use and CRM adoption in B2B firms. CRM software in companies activities have a significant importance to improve the competitive advantage by understanding better customer needs. Fifty percent of worldwide projects on CRM systems are failing because marketing managers and CEO have the belief that CRM will solve all their company problems. CRM is not only used as a marketing and business tool but a complex combination tool that is applied in various business areas. CRM system aims to the creation of mutual satisfactory long term relationships between buyers and purchasers. The findings reveal that firms apply traditionally CRM processes such as sales and customer service even if they are aware of using Information Technologies in order to interact with clients.
\end{abstract}

Keywords: Customer Relationship Marketing, Information Technology, Business to Business

\section{Introduction}

Customer Relationship Marketing has emerged during last years and became an important marketing tool that focuses on the building and retaining long term relationships with clients.

There is a positive effect of the CRM use in customer knowledge and customer satisfaction examining 360 U.S.A. firms $[10,30]$. CRM strategy facilitates the organizational learning process for clients because enables firms to understand better purchase behavior in transactions [20, 27]. Also, CRM use has positive impact in customer relational and profit performance and creates advantages for firms by improving its information to guide them in successful and profitable relationships. Examined in their survey that CRM application includes front office applications that supports sales marketing and services and back office applications that helps to fulfill and analyze information collected [30]. There is a positive impact of CRM oriented firms in their customer relationship performance. There is a positive impact in customer retention and sales growth and profit with CRM $[31,33]$.
On the other side Internet, have increased clients expectations for a shorter time of response to their needs [26]. The continuous development of Information technologies and its interaction with marketing are a resource to create value for the customer [20, 24]. Marketers have to use the new technology and customer information in order to improve their response to customer expectations [29, 24]. In the Greek Industrial Market CRM and Information Technology use followed by Greek companies and affects positively in their trials to expand their activities. Other CRM software in companies activities have a significant importance to improve the competitive advantage by understanding better customer needs [10]. The aim of this research is to approach effectively CRM application at Greek companies that are activated in the consumer products sector. The objective of the research is to investigate how CRM strategy and Information Technology affect B2B relationships. Moreover, it is examined the impact of firms' size and its relation with technology adoption. 


\section{Theoretical Issues and Review of Empirical Literature}

\subsection{Defining Customer Relationship Marketing}

There are two main different approaches that support CRM practices, Nordic School that focusing in services marketing and International Purchasing Group IMP, that focuses in Industrial Marketing [25]. Nevertheless the term relational marketing becomes more frequent in studies on late $80 \mathrm{~s}$ decade. Relationship marketing concerns attracting, developing, and retaining customer relationships, it refers to all marketing activities towards establishing, developing, and maintaining successful relational exchanges with customers.

In a more integrated approach $[12,15]$ include also stakeholders by defining RM that identify and establish, maintain, and enhance relationships with customers and other stakeholders, at a profit, so that the objectives of all parties involved are met; and this is done by a mutual exchange and fulfilment of promises. They state that is not necessary only to attract partners and to create a transactional relationship but also to increase the relations through the delivery of promise. Refers to the role promises in RM and argues that it is very important the accomplishment of promises given [15]. Promises can attract new customers and to create relationships although if promises given would not be realized the relationship cannot be continued. RM is a strategic orientation that applied both from customer and purchaser and represents the endearment to a long term mutual profitable relationship as marketing based on interaction within networks of relationship [17, 18]. CRM aims to the creation of mutual satisfactory long term relationships between buyers and purchasers [23]. Companies must develop stronger bonds with their customers and stakeholders and firms should focus to be moved from short term oriented transactions to build long term relationships [23]. Relationship Marketing is based on the theoretical perspective that exists during a continuum of relations of customers with suppliers that aims primarily to achieve simple transactions with customers and can achieve the adoption of mutual long term relations with customers.

\subsection{Relationship Marketing and Information Technology}

CRM can be defined as a marketing approach that enables companies to attract and increase the retention of profitable customers by managing its relationships with them [4]. These relationships can be managed through traditional CRM policies, personal selling and through Internet or telecommunication systems. Justifying this approach have stated that the rapid growth of the Internet, Information Systems and other related technologies has created a challenge for marketing and has changed the way of relationships between companies and their customers [1]. Moreover argues that Information Technology can be used to automate all CRM processes [22]. Thus it is assumed that the use of IT services can enable the collection of the necessary data and enhance customer retention and the value of life time.
In an older but fundamental approach of RM, argues that the deployment of new technologies gives an insight to the growth rate of CRM applications [15]. The implementation of CRM effects on various operations within the firm including sales, Marketing, Financial Services and IT operations. There are two divisions in the relation with the customer: The first division is to attract the customer and the second to build the relationship with that customer and thus only the economic goals of that relationship will be achieved [15].

It is assumed that there is a strong relation and mutual interaction between CRM and ECRM applications through IT Systems.

Internet technology can be viewed as a provider of better business opportunities for companies to establish their distinctive strategies. Therefore businesses in order to gain such a competitive advantage will not require radically new approaches.

Initially, CRM consecrated in marketing sector and extending as business practice on the late 1990s. This happened because of rapid changes in information technology and data management systems, informative systems integration and the rapid extension of the Internet [11].

Information Technologies and the adoption of new communication tools supports business to offer customized products and services to their customers by collecting information, demographic data, channel preferences and customer purchasing behavior. With such tools marketers are able to create special customized products and services improving their loyalty to customers, gaining greater customer share and enhancing business profit over time [23].

\subsection{CRM vs E-crm}

Some argue that a relationship can be developed only when all or at least the most major customer relations and interactions are oriented to relationship build approach [12, 15]. Therefore enterprises should set as a main goal to create interaction and communication processes to facilitate a relationship. In order to achieve the objectives of both parties customer-supplier Relationship Marketing should aim to identify, establish, maintain and enhance or when necessary to terminate relationships with customers.

The E-Customer relationship management is described as one of the marketing tools that firms use to increase and empower their marketing capabilities. ECRM systems in the form of IT databases or other communication systems are growing rapidly over the last years. The implementation of such systems and Enterprise Resource Planning systems has created obvious opportunities for companies.

These implementation systems and enterprise resource planning systems in most cases reduplicates the existing CRM process through the use of a new database of information technologies. The sixty percent of medium sized companies present an intention to set up activities or to expand their CRM usage to specialized companies and on the other side only a two percent presents the tension that they had no future plans to apply a CRM system [27]. 
An effective ECRM system should give to a company the opportunity to communicate effectively and efficiently with customers using a single voice [27]. Information collected through CRM and improves company's ability to identify the costs of acquiring or retaining a customer. ECRM systems are a method that has developed in Greek companies the last years, so the research will try to create a combinational framework of the emerged area of ECRM systems of companies in traditional CRM implementation.

\subsection{Advantages of CRM and ECRM}

A survey concludes that a ten percent gain to retain customers can add ten percent more to company profits and that a ten per cent reduction of marketing expenses for new customers ads only a seven percent profit [27]. It has been proved that if a company of high technology invest a billion dollars for managing its CRM it would have profits thirty millions and that an ECRM performance is a major factor to return the sales return profits.

The customer retention is the most important and the key success factor is the retention of profitable relations with customers and it is more expensive to acquire a new customer than to make an existed one satisfied. This strategy can reduce costs and to increase the technological cooperation as improves the firm's profit because of protecting the customer base by offering customized products and creating barriers for changing supplier [21]. CRM movement will grow despite its early failures and will target to loyalty programs, affinity marketing and campaign management [24].

Below presents the benefits of business by using CRM.

a) Lower cost to recruit customers. Any cost that arise from recruiting customers process e.g. mails, follow up, marketing are fully automated by using CRM so there are important savings for business in this process.

b) By using CRM will be increased the number of long term customers so it will not be needed to recruit new customers for a stable sales volume.

c) Reduced sales expenses and sales cost. CRM provides a better knowledge for communication channels, automates campaigns so the process to acquire new customers is less expensive for the firm user of CRM.

d) Improved customers' profitability. A greater customer satisfaction will lead to higher purchase volume because of improved follow up and cross sales possibilities that are developed by using CRM.

e) Improved customer retention rate. Customers obtain better and immediate service from the supplier user of CRM.

f) Improved loyalty to customer. Improved interaction in the relation leads the customer to take initiatives and to feel committed in this relationship.

g) Evaluation of customers' profitability. Sales results and customers purchasing behavior are observed easily by using a CRM system. Customer profitability is considered a key factor to terminate or invest on a relationship.
In order to define which of the customers are profitable and which are not it is proposed a continuum of relational and transactional parameters. Customers should be located at this continuum and separated according to their preferences for a transactional focus or a relational focus to the supplier. Customers that will be categorized in a transactional focus should have a lower importance from the business [5]. Relationships should be established only with customers that are seeking this relationship and customers that are transactional focused should be outsourced [24]. Fifty percent of worldwide projects on CRM systems are failed because marketing managers and CEO have the belief that CRM will solve all their company problems. This happened because companies even if they invest and purchase a CRM system they do not realize in such investments is necessary to educate their stuff. The Institute for Business Value concludes that seventy five percent of firms that purchase a CRM system they use it only in a whole sector mainly to marketing, sales and customer service departments and only a minority of them $25 \%$ they purchase it strictly for managerial use. Reasons of CRM failure according to founds of Forsyth research in a sample of 700 USA firms can be the Organizational change (29\%), companies remission to apply its CRM strategy, low level of knowledge of CRM (20\%) and low level CRM skills (6\%). It is assumed that nowadays companies they do realize investments in CRM software systems although these systems does not meet exactly managerial expectations on return on investment or managers they do not count the real value perceived from CRM applications.

CRM is not only used as a marketing and business tool but a complex combination tool that is applied in various business areas. In the follow is presented a description of the main tools of CRM [8].

a) Marketing automation

Marketing automation means to offer the proper product to the proper customer at the moment that he needs it through the proper channel. CRM supports to Marketing information for products and services offered to the customers, evaluation of product opportunities, product positioning and follow up of customer contacts. Also includes marketing tools to analyze data for customers in order to define which customers are profitable, to design new products customized to customer needs [8].

b) Direct Marketing enables the direct communication to a great number of customers at the same time [8].

It is about the separation of a market in different groups, each group includes customers with similarities in their needs, profitability factors, size, geographical data, psychographic data, and preferred sales channels.

c) Campaign management

Up-dated information use for customers enables sales force to approach more effectively their customers in one to one marketing.

d) Cross Selling

It is more easy and effective to increase sales volume to one customer than to try to acquire new customers. Automation processes of CRM can enable companies to achieve cross selling more effective having the knowledge of 
predictability which customers are positively respond to the certain products [8].

e) Sales force automation

CRM enables Sales force to spend less time to handle administrative matter. Additionally CRM provides important tools such as key customer tasks, alarm reminders, a list for pending matters to do and time estimation for the duration of pending activities [8].

CRM enables information for existed and potential customers to be disseminated easily among sales departments and marketing. Increases the effectiveness of sales force, reduces the cost per each selling required and acquisition cost of a new customer.

f) Sales Performance evaluation and analysis

Figures of sales are analyzed automatically and categorized by geographical areas, customer accounts, total sales volume, order volume, distribution channel, and sales growth. Comparative results are a useful tool for sales force to budget and design future actions and strategies. Furthermore it is given to managers information for which sales force may need more training to achieve their targets, bonuses given to them, if there are needs to terminate or to hire sales personnel.

a) Contact Management

Contact management refers to information that is collected from contacts with customers, their position in the company, past interaction of customers with the supplier, visits to the customer.

b) Knowledge management

Knowledge Management consists a data base related to sales presentation files, company contact list of emails/phone number, event notes and trade shows information, competitor data, past sales reports. Access to this information is vital for the sales force. Knowledge management can be used also independently from CRM as a separated business practice.

c) Customer Service and Support

Customer Service provides information and tools to increase effectiveness of contact customer centers, services and support center enabling the access to accurate information can help customer contact center to reduce the time needed to serve a customer.

The certain survey was been conducted in the Greek industrial market exclusively in the consumer products sector. The consumer products sector has a very important role in the Greek economy and represents approximately $21 \%$ of Greek manufacturing industry that includes 1,350 enterprises and occupying 70,000 employers. Main produced products are dairy products, meat products, fruits and vegetables processing industries, olive oil manufacturers.

\section{Methodology}

The participants in the research were firms from the Greek consumer products sector that they apply CRM technology or they apply Relationship Marketing without a software support of CRM. They have knowledge of CRM technology and they have the willingness to participate in the certain research. It was used the data base of Greek Union of Consumer products Industries that represents the $85 \%$ of Greek consumer products industries. Also database used such as the database of Statbank consulting (www.statbank.gr). The snowball sampling was used to find the related firms. We addressed to 370 firms and responded 73 participants with a rate of respond $19,8 \%$. The respondents' present higher sales volume. According to European Committee small sized firms are considered the firms with personnel between 10-49 persons, very small are characterized the firms that occupying less than 10 persons, Small medium industries are them that have from 50 up to 249 personnel, and Medium sized the firms that have more than 250 persons employers. In the present research was contacted with medium and small-medium sized firms because they were aware of Relationship Marketing and there were a related responsible contact person in Marketing and Sales department to respond to the questionnaire. In the majority of cases in small or very small firms usually it was responded by general manager or management assistant. The questionnaires have been sent via e-mail to them after contact and were sent back completed.

\subsection{Data Presentation and Interpretation}

In the first table 1 firms have a clear tension to use new Information technologies for supporting their relations (Aver=5, 36). Also there is a low tension of firms to automate their activities, automation of Sales force tools (aver=4, 56) and automation of customer service (aver. $=4,17$ ) the average measurement is almost insignificant, (4=neither agree / disagree according to likert scale). Such as slightly insignificant is the response for maintaining electronic files for customers (Aver. $=4,95$ ). In the contact process with their customers is concluded that there is a clear tension for frequent contact with customers (Aver. $=5,76$ ) and frequent data collection (Aver. $=5,87$ ) as in the collection process of data related to customers (Aver. $=5,86$ ). Additionally it is presented that firms connect all the collected information (aver. $=5,41$ ) and disseminate these data in all of the firm sectors (aver. $=5,31$ ).

Table 1. Advantages from CRM use.

\begin{tabular}{|c|c|c|c|c|}
\hline \multicolumn{5}{|l|}{ Descriptive Statistics } \\
\hline & $\mathbf{N}$ & Sum & Mean & Std. Deviation \\
\hline In our company Information Technology tools supports our relations with Industrial Customers & 73 & 392,00 & 5,3699 &, 73611 \\
\hline CRM application in our company is supported by a related software of managing relations & 73 & 338,00 & 4,6301 & 1,79897 \\
\hline Available sales force tools are fully automated in our firm & 73 & 333,00 & 4,5616 & 1,17835 \\
\hline Customer contact centre and customer service is a fully automated process & 73 & 305,00 & 4,1781 & 1,15881 \\
\hline In our firm customer data source is available through electronic files & 73 & 361,00 & 4,9452 & 1,54462 \\
\hline
\end{tabular}




\begin{tabular}{|c|c|c|c|c|}
\hline \multicolumn{5}{|l|}{ Descriptive Statistics } \\
\hline & $\mathbf{N}$ & Sum & Mean & Std. Deviation \\
\hline New customers approach is a fully automated process & 73 & 277,00 & 3,7945 & ,91225 \\
\hline Our customers can contact our firm through various ways (fax, tel. mail etc.) & 73 & 396,00 & 5,4247 & ,92673 \\
\hline We are focused to contact our customers frequently & 73 & 421,00 & 5,7671 &, 63510 \\
\hline We frequently collect information for our customers & 73 & 429,00 & 5,8767 &, 57603 \\
\hline We use to up-date information that are collected for our customers & 73 & 428,00 & 5,8630 &, 58488 \\
\hline $\begin{array}{l}\text { We connect all the information collected for our customers that became from different } \\
\text { communication channels }\end{array}$ & 73 & 395,00 & 5,4110 & 1,05192 \\
\hline All data sources of customers are easily accessible to our firms personnel & 73 & 388,00 & 5,3151 & ,89562 \\
\hline Valid N (listwise) & 73 & & & \\
\hline
\end{tabular}

It is observed in Table 2 that there is a tension of companies to be Customer oriented according. Except of the second question related to an integrated customer centric orientation of the company Companies Average measurement data $(5,12 \mathrm{~min} .-5,90 \mathrm{max}$.) present their strategic focus to serve customer needs. Also that it is mainly up to sales and marketing sector to serve these needs because of the average measurement of firms answers $(4,20)$ that respond almost insignificantly in the question if all their sectors are focused to fulfil customers' expectations.

Table 2. Customer Market Orientation Measurement.

\begin{tabular}{|c|c|c|c|}
\hline & $\mathbf{N}$ & Aver. & St. Dev. \\
\hline Our company acts immediately when comes the information for unfulfilled customer needs within all its departments & 73 & 5,9041 & ,338 \\
\hline All our business segments ( not only sales and marketing) are focused to fulfil customers expectations & 73 & 4,2055 & 2,610 \\
\hline All our business functions are focused to fulfil customers' needs in targeted markets & 73 & 5,3699 & ,709 \\
\hline Our strategy to improve our firms competitive advantage is based on deep understanding of our customer needs & 73 & 5,7260 & ,729 \\
\hline All our business segments can understand how to handle our functions in order to create value for our customers & 73 & 5,1233 & 2,665 \\
\hline In case that our major competitor promoted a campaign to gain our customers we could respond immediately & 73 & 5,6027 & ,798 \\
\hline Our firm in all of its segments responds immediately to negative customer comments & 73 & 5,6986 &, 575 \\
\hline
\end{tabular}

After the analysis for the evaluation of Customer relationship marketing strategies in the firm, we observe a clear view of firms that CRM is a useful tool with the following importance range:

1. Increase of Sales Volume (aver. 5, 73)

2. Increase of Market Share (aver. $=5,61$ )

3. Increase customer retention $(5,54)$

4. Improves the process of maintain communication channels (aver. $=5,47$ )

5. Affected positively profits, acquisition of new customers and reduces the time of response to customer needs (aver. $=5,35$ )

6. Provides companies with the possibility to sell the appropriate product to the proper customer (aver. $=5,32$ )

7. Reduces sales expenses (aver. $=5,31$ )

8. Help companies to be informed for sales volume per sector and customer and improves the customer service process (aver. $=5,30$ )

9. Affected positively contacts with new customers and creates automated processes that fit to customer needs (aver. $=5,29)$

10. Improve the Corporate understanding for customer needs (aver. $=5,28)$

11. Provides with a Knowledge of better understanding of competition (aver. $=5,22)$

12. Improves relations with customers and helps in the decision making process (aver. $=5,15$ ).

On the other hand companies do not consider as insignificant the usefulness of Customer Relationship Marketing Process in the following statements.

1. Provide them with information for new customer trends (aver. $=4,30)$
2. Help companies in their pricing policies (aver. $=4,37$ )

3 . Helps to improve products quality (aver. $=4,52$ )

4. Helps to improve corporate competitive advantage (aver. $=4,54)$

5. Eliminate the possibility to lose market share from competitors (aver. $=4,65$ )

Measuring which of the applications of CRM are used in the firms' respondents totally agree $(100 \%)$ in supply, to their sales force with information for customers, then it is noticed the use of it to supply to the management information for the sales results, information to approach potential customers in figure 1 .

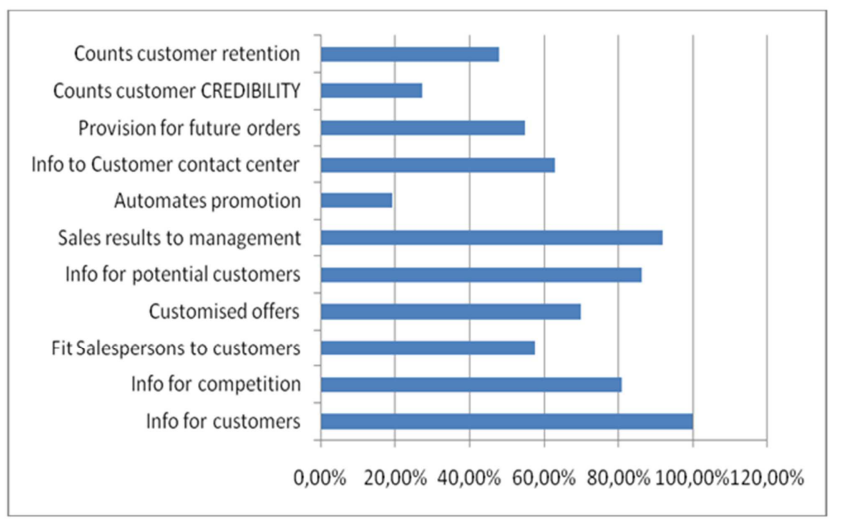

Figure 1. Customer Relationship Marketing measurement.

In the table 3 because of the rapid development of internet communication and information technology tools, companies still have a greater tension to collect off line information for their customers $(84,9 \%)$. Off line information collection is related to internal files of company in order to select the 
information that they are seeking for.

Table 3. Sources of information for customers.

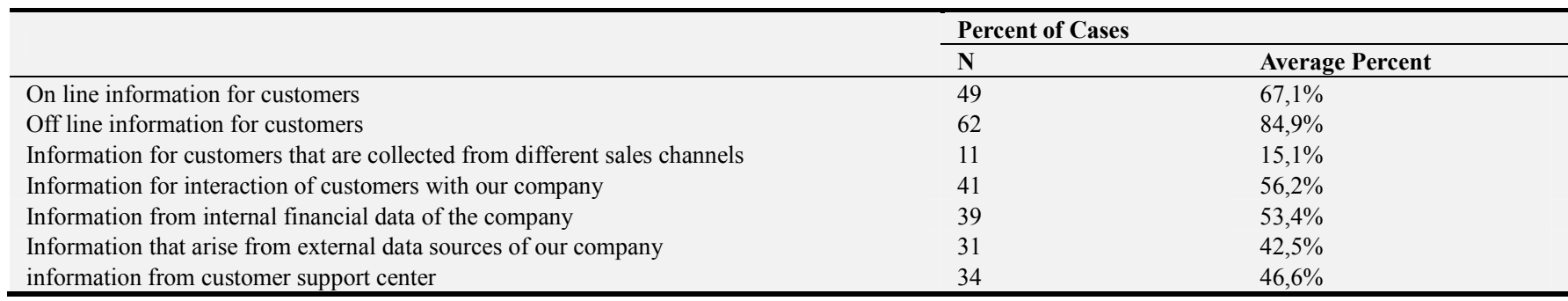

\subsection{Application of CRM in Firms' Departments}

CRM is considered as a tool that is applied mainly by the sales department $(100 \%)$, then marketing and customer service and only a few percentage of respondents (below to $50 \%$ ) is applied in Logistics, financial and customer account department.

Observing the tables 4, 5, 6 it is assumed that in Hypothesis for correlation between Automation of Sales force tools and Information Technology use in supporting relations with customers is insignificant because $p=0,079>$ 0,05 . So it is assumed that Support of Information technology in relations with customers is insignificant to the automation of sales force tools. Customer contact and customer service automation are also not correlated with the support of Information Technology systems in relations with customers because $p=0,485>0,05$. Therefore customer contact and customer service automation process is not correlated with the use of Information Technology tools in the relationships with customers.

Table 4. Correlation of Information Technology tools use with automation of sales process.

\begin{tabular}{lllll}
\hline Model Summary & & & \\
\hline Model & R & R Square & Adjusted R Square & Std. Error of the Estimate \\
\hline 1 &, $503^{\mathrm{a}}$ &, 253 &, 220 &, 65001 \\
\hline
\end{tabular}

a. Predictors: (Constant), New customers approach is a fully automated process, Available sales force tools are fully automated, Customer contact center and customer service is a fully automated process

Table 5. $A N O V A^{b}$.

\begin{tabular}{llllll}
\hline Model & & Sum of Squares & df & Mean Square & Sig. \\
\hline \multirow{2}{*}{1} & Regression & 9,860 & 3 & 3,287 &, $000^{\text {a }}$ \\
& Residual & 29,154 & 69 &, 423 & \\
& Total & 39,014 & 72 & & \\
\hline
\end{tabular}

a. Predictors: (Constant), New customers approach is a fully automated process, Available sales force tools are fully automated, Customer contact center and customer service is a fully automated process

b. Dependent Variable: In our company IT information systems supports our relations with Industrial Customers

Table 6. Coefficients ${ }^{a}$.

\begin{tabular}{|c|c|c|c|c|c|c|}
\hline \multirow{2}{*}{\multicolumn{2}{|c|}{ Model }} & \multicolumn{2}{|c|}{$\begin{array}{l}\text { Unstandardized } \\
\text { Coefficients }\end{array}$} & \multirow{2}{*}{$\begin{array}{l}\text { Standardized } \\
\text { Coefficients } \\
\text { Beta } \\
\end{array}$} & \multirow[t]{2}{*}{$\mathbf{t}$} & \multirow[t]{2}{*}{ Sig. } \\
\hline & & B & Std. Error & & & \\
\hline \multirow{4}{*}{1} & (Constant) & 3,707 &, 367 & & 10,105 & ,000 \\
\hline & Available sales force tools are fully automated &, 138 & 077 & ,221 & 1,784 & ,079 \\
\hline & Customer contact center and customer service is a fully automated process &,- 065 & ,093 &,- 103 &,- 702 & ,485 \\
\hline & New customers approach is a fully automated process & ,344 &, 118 &, 426 & 2,912 &, 005 \\
\hline
\end{tabular}

a. Dependent Variable: In our company IT information systems supports our relations with Industrial Customers

Automation process in tables 7,8 in approaching new customers also is insignificant to Information Technology tools use from companies in supporting relations with customers. In the certain case $p<0,05$ the Hypothesis it is accepted.

Table 7. CRM Implementation by a special CRM software is correlated in contacting by an automated process new customers.

\begin{tabular}{|c|c|c|c|c|c|c|}
\hline \multicolumn{7}{|l|}{ Case Processing Summary } \\
\hline & \multicolumn{6}{|l|}{ Cases } \\
\hline & Valid & & Missing & & Total & \\
\hline & $\mathbf{N}$ & Percent & $\mathbf{N}$ & Percent & $\mathbf{N}$ & Percent \\
\hline $\begin{array}{l}\text { CRM application in our company is supported by a related software of managing } \\
\text { relations * New customers approach is a fully automated process }\end{array}$ & 73 & $100,0 \%$ & 0 &, $0 \%$ & 73 & $100,0 \%$ \\
\hline
\end{tabular}


Table 8. Chi-Square Tests.

\begin{tabular}{|c|c|c|c|c|c|c|c|c|c|}
\hline & \multirow{3}{*}{ Value } & \multirow{3}{*}{ df } & \multirow{3}{*}{$\begin{array}{l}\text { Asymp. Sig. } \\
\text { (2-sided) }\end{array}$} & \multicolumn{3}{|c|}{ Monte Carlo Sig. (2-sided) } & \multicolumn{3}{|c|}{ Monte Carlo Sig. (1-sided) } \\
\hline & & & & \multirow{2}{*}{ Sig. } & \multicolumn{2}{|c|}{ 95\% Confidence Interval } & \multirow{2}{*}{ Sig. } & \multicolumn{2}{|c|}{ 95\% Confidence Interval } \\
\hline & & & & & Lower Bound & Upper Bound & & Lower Bound & Upper Bound \\
\hline Pearson Chi-Square & $32,281^{\mathrm{a}}$ & 20 & 040 &, $084^{\mathrm{b}}$ & 078 & 089 & & & \\
\hline Likelihood Ratio & 38,640 & 20 &, 007 &, $002^{\mathrm{b}}$ &, 001 & 002 & & & \\
\hline Fisher's Exact Test & 36,927 & & &, $002^{\mathrm{b}}$ &, 001 &, 002 & & & \\
\hline Linear-by-Linear Association & $23,463^{\mathrm{c}}$ & 1 &, 000 &, $000^{\mathrm{b}}$ &, 000 &, 000 &, $000^{\mathrm{b}}$ &, 000 &, 000 \\
\hline $\mathrm{N}$ of Valid Cases & 73 & & & & & & & & \\
\hline
\end{tabular}

a. 26 cells $(86,7 \%)$ have expected count less than 5 . The minimum expected count is, 03 .

b. Based on 10000 sampled tables with starting seed 2000000 .

c. The standardized statistic is 4,844 .

Table 9. Significance of arguments.

\begin{tabular}{|c|c|}
\hline Model & Sig. \\
\hline (Constant) & ,540 \\
\hline CRM has affected positively to our sales volume & ,396 \\
\hline CRM has affected positively to our market share & ,674 \\
\hline CRM has affected positively customer retention & ,281 \\
\hline CRM has affected positively to improve our relations with our customers & ,922 \\
\hline CRM has affected positively to improve our customer service & ,163 \\
\hline CRM has affected positively to improve our understanding for our customer needs & ,692 \\
\hline CRM has affected positively to the response time to our customer needs & ,027 \\
\hline CRM has affected positively to the better understanding of competition and its products & ,699 \\
\hline CRM has affected positively to increase our sales profits & ,266 \\
\hline CRM has affected positively to the acquisition of new customers & ,605 \\
\hline Data collection from CRM have affected positively the success in contacting new customers & ,078 \\
\hline CRM can improve the maintaining of communication channels with our customers & ,041 \\
\hline CRM can give us the possibility to sell the proper product to the related customer & ,812 \\
\hline CRM has created automated processes according to customers response & ,969 \\
\hline CRM can help us in new customer to recognize trends and needs according to our customer needs & ,439 \\
\hline CRM can help us in our price policy strategy &, 883 \\
\hline CRM can help us in decision making in our firm & ,867 \\
\hline CRM can help us in examining sales volume per sector and customer & ,036 \\
\hline
\end{tabular}

\section{Discussion of Findings and Recommendation}

The research investigates the adoption of CRM Technology to determine the level of CRM software adoption and Information Technology use in implementing CRM in managing relationship with customers. The most important reason for collecting data for customers is the collection of demographic data information.

Customer Relationship Management process in its field of use presents as most popular activity to supply to sales force information for customers. Most Important acknowledgment in the positive result of CRM implementation was the Increase of sales volume. Customer Relationship Marketing in companies is related primarily to sales department and customer service department. There is a tension of firms to apply traditionally processes such as sales and customer service and even if they are aware of using new Information Technologies to keep standardized their main processes related to interaction with customers. Although on the other side firms in case that they support their relations with customers present a positive tension to automate their sales process.
There is a clear tension for recognition of CRM positive results as a process and not as exclusively supported by software. CRM software support in relations with customers improve the maintaining of communication channels with their customers and reduce sales expenses.

In a continuously competitive environment which financial crisis strongly affects the organizational buying behaviour, CRM can be the driver for organizations in order to retain their clients satisfied and to create advantages over competitors. Firms have recognized that in order to build a sustainable competitive advantage in the global market is required primarily to become a trusted participant in various networks.

\section{References}

[1] Bayon, T., Gutsche, J., and Bauer H., (2002), Customer equity marketing: touching the intangible, European Management Journal, Vol. 20 No. 3, pp. 213-22.

[2] Bell J. \& Johnston, W. J. (2004). An evaluation of divergent perspectives on customer relationship management: Towards a common understanding of an emerging phenomenon. Industrial Marketing Management, 33 (6), 475-489. 
[3] Berry, L. L. (1995). Relationship marketing of services Growing interest, emerging perspectives. Journal of the Academy of Marketing Science, vol. 23, pp/ 236-245.

[4] Bradshaw D., Brash, C. (2001), Managing customer relationships in the e-business world how to personalise computer relationships for increased portability, International Journal of Retail \& Distribution Management, Vol. 29 No 11/12, pp. 520-30.

[5] Brennan, D. R., Turnbull, P. W., \& Wilson, D. T. (2004). Dyadic adaptation in business-to-business markets. European Journal of Marketing, 37 (11/12), 1636- 1665.

[6] Crosby, L. A., \& Johnson, S. L. (2001). High performance marketing in the CRM, Marketing Management, vol. 10, 1011 .

[7] Dwyer, F. R., Schurr, P. H., \& Oh, S. (1987). Developing buyer-seller relationships. Journal of Marketing, Vol. 51 pp. 14-26.

[8] Dyché, J. (2002). The CRM handbook: A business guide to customer relationship management. Published by Addison Wesley editions Boston (2002).

[9] Ganesan, Shankar (1994), "Determinants of Long-Term Orientation in Buyer-Seller Relationships", Journal of Marketing, 58, pp. 1-19.

[10] Gefen, D., Straub, D. W., \& Boudreau, M.-C. (2000). Structural equation modeling and regression: Guidelines for research practice. Communications of the Association for Information Systems, 4, 1-7.

[11] Greenberg P. 2002 Customer Relationship Marketing at the speed of light Capturing and keeping customers in Internet Real Time. Published by Mac Graw Hill Editions.

[12] Gronroos (2000) Service Management and Marketing: A customer Relatioship Management approach Published By Wiley publications New York.

[13] Grönroos, C. (1990). Relationship approach to marketing in service contexts: The marketing and organizational behavior interface. Journal of Business Research.

[14] Grönroos, C. (1994). Toward a relationship marketing aradigm. Journal of Marketing Management, Vol. 10, pp. 347360. Grönroos, C. (1996). Relationship marketing: Strategic and tactical implications. Management Decision, Vol. 34.

[15] Gronroos, Christian (1999), "Relationship marketing: challenges for the organization", Journal of Business Research, 46, pp. 327.

[16] Gumesson E. (1999) Total Relationship Marketing: Rethinking Management from 4ps to 30rs published by Butter worth Heinemann New York.

[17] Gummesson, E. (2002). Relationship marketing and a new economy: It's time for deprogramming. Journal of Services Marketing, Vol. 16 586-589.

[18] Gummesson, E. (2004). Return on relationships (ROR): The value of relationship marketing and CRM in business-tobusiness contexts.
[19] Gwinner K., Gremler D., Bitner M. (1998) Relational Benefits in services industries the customer's perspectives, Journal of the Academy of Marketing Science Vol. 26.

[20] Hendricks, K, Singhal, V., and Stratman, J. (2006). The impact of enterprise systems on corporate performance: Journal of Operations Management, vol. 25, pp. 65-82.

[21] Homburg C. \& Cannon, J. (2001). Buyers-supplier relationships and customer firm costs. Journal of Marketing, vol. 65 , pp. 31-42.

[22] Kincaid J. (2003), Customer Relationship Management: Getting it Right, published by Prentice-Hall editions 2003, New Jersey.

[23] Kotler, P. (1970). The future of the computer in marketing. Journal of Marketing, vol. 34, pp. 11-14.

[24] Parvatiyar, A., \& Sheth, J. N. (2000). The domain and conceptual foundations of relationship marketing. In J. N. Sheth \& A. Parvatiyar (Eds.), Handbook of relationship marketing (pp. 3-37).

[25] Rao, Sally, and Chad Perry (2002), "Thinking about relationship marketing: Where are we now?", Journal of Business Marketing, vol. 17. pp. 598-614.

[26] Roberts, K., Varki, S., \& Brodie, R. (2003). Measuring the quality of relationships in consumer services: An empirical study. European Journal of Marketing, vol. 37, pp. 169-176.

[27] Romano N., Scullin S., Fjermestad J., (2004) E-relationship marketing: changes in traditional marketing as an outcome of electronic customer relationship management The Journal of Enterprise Information Management Volume 17 Number 6 2004 pp. $410-415$.

[28] Sarkar, M. Aulakh and S. T. Cavusgil (1998), "The strategic role of relational bonding in interorganizational collaborations: Journal of International Management 4, pp. 85107.

[29] Storbacka, K., Strandvik, T., \& Grönroos, C. (1994). Managing customer relationships for profit: The dynamics of relationship quality. International Journal of Service Industry Management, 5 (5), 21-38.

[30] Verhoef, P. C. (2005). Understanding the effect of customer relationship management efforts on customer retention and customer share development. Journal of Marketing, 67 (4), $30-45$.

[31] Wilson, D. (1995), An Integrated Model of Buyer-Seller Relationships, Journal of the Academy of Marketing Science, 23, pp. 335-343.

[32] Wright, L. T., Stone, M., \& Abbott, J. (2001). The CRM imperative - Practice and theory in the telecommunications industry. Journal of Data Marketing, vol. 9. pp. 339- 349.

[33] Yau, Lee, Sin, \& Chow, R. P. M. (2002). The effect of relationship marketing orientation on business performance in a service-oriented economy. Journal of Services Marketing, 656-676. 